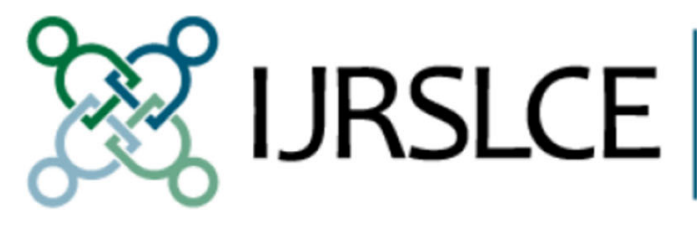

International Journal

for Research on

Service-Learning \&

Community Engagement

\title{
Does Location Really Matter? Exploring the Role of Place in Domestic and International Service-Learning Experiences
}

\author{
Elizabeth K. Niehaus \\ Crystal E. Garcia
}

This article was originally published at:

https://journals.sfu.ca/iarslce/index.php/journal/article/view/288/193

Recommended Citation

Niehaus, E. K., \& Garcia, C. E. (2017). Does location really matter? Exploring the role of place in domestic and international service-searning experiences. International Journal of Research on Service-Learning and Community Engagement, 5(1), 99-118. 


\title{
Does Location Really Matter? Exploring the Role of Place in Domestic and International Service-Learning Experiences
}

\author{
Elizabeth K. Niehaus \\ University of Nebraska-Lincoln
}

Crystal E. Garcia

Auburn University

\begin{abstract}
Although increasingly popular, international/global service-learning programs are not without critique; in fact, the role of crossing national borders in service-learning is highly contested. The purpose of the study discussed in this article was to explore this role of crossing borders within the context of a particular experience: participation in an alternative break (AB) program. The authors sought to understand whether there is an aspect of learning in specific places, namely learning across national borders, that is separate (and separable) from what happens in those places. Participants reported a high level of influence of their $\mathrm{AB}$ experience on both their intentions to volunteer and to travel internationally, although there were a number of differences between students who participated in domestic and international ABs. Mediation analysis showed that the relationship between program location and the influence of the $\mathrm{AB}$ on students' plans to volunteer was mediated completely by features of the $\mathrm{AB}$ program itself, while the relationship between program location and the influence of the $\mathrm{AB}$ on students' plans to travel internationally was only partially mediated by program features.
\end{abstract}

Keywords: international service-learning, college students

Throughout their history, institutions of higher education have engaged in international and cross-border activities (Altbach, 2004; de Wit, 2002); yet, social, political, and economic changes over the past few decades have repositioned higher education institutions within a broader context of globalization.

Recently, governments, professional associations, students, and universities themselves have issued a call to internationalize higher education (e.g., American Council on Education, 2002; IIE, 2014). One central way institutions have responded to this call is by increasing opportunities for students to study abroad or engage in international service-learning, under the assumption that these experiences promote intercultural learning and global citizenship (Paige \& Vande Berg, 2012; Woolf, 2007).

The call to internationalize higher education, however, and in particular the use of cross-border travel as a primary means of doing so, has been contested. In critiquing study-abroad programs, Woolf (2007) argued that the field of study abroad is filled with assumptions about the benefits of immersion in a "foreign" culture that are often unproven. International service-learning (ISL) programs are subject to even stronger criticism, including concerns about student safety (Rubin \& Matthews, 2013), damage to host communities (Schroeder et al., 2009; Wood et al., 2011), and the development of "paternalistic and ethnocentric attitudes through service relationships" (Piacitelli, Barwick, Doerr, Porter, \& Sumka, 2013, p. 92). Some scholars (e.g., Jacoby, 2009; Sobania, 2015) have gone so far as to argue that international experiences are unnecessary or that domestic cross-cultural experiences can serve the same purposes as international programs. With the high cost of international travel serving as a potential barrier to engagement in ISL and other international experiences, it is particularly important to examine what differences, if any, exist between international and domestic experiences.

Although some arguments in support of the value of both international and domestic crosscultural experiences are valid, little empirical research has isolated the specific role crossing national 
borders plays in student outcomes. One of the difficulties in isolating this role is that domestic and international experiences are often different in ways inseparable from the locations in which they occur. For example, studying abroad and studying on campus in the United States for a semester are so vastly different that it is often impossible to separate out the specific effect of the actual experience abroad (e.g., Golay, 2006; Orhood, Kruze, \& Pearson, 2004). Alternative breaks (ABs), however, provide one context for comparing similarly structured international and domestic experiences. ABs are opportunities for small groups of students to engage in service-learning during their academic breaks, often involving travel to a different city, state, or country. Typically, AB programs pair direct service with learning about a particular social issue (Break Away, 2014).

The purpose of this study was to explore the role of crossing national borders within the context of one particular experience: participation in an $A B$ program. We sought to understand whether there is an identifiable aspect of learning in specific places - namely learning across national borders - that is separate (and separable) from what happens in those places.

\section{Theoretical Frameworks: Global Service-Learning and Place-Based Education}

In contrast to international service-learning, Hartman and Kiely (2014b) defined global servicelearning (GSL) as "a community-driven service experience that employs structured, critically reflective practice to better understand common human dignity; self; culture; positionality; socio-economic, political, and environmental issues; power relations; and social responsibility, all in global contexts" (p. 60). Importantly, they argued that GSL experiences can happen within an international or a domestic setting, so long as the content of the experience focuses on critical global citizenship (Hartman \& Kiely, 2014a), pairing "structural analysis tied to consideration of power, privilege, and hegemonic assumptions" (Hartman \& Kiely, 2014b, p. 56) with active engagement in social change.

Hartman and Kiely's (2014b) framing of GSL builds on the work of others, such as Longo and Saltmarsh (2011), who have argued for a focus on global rather than international service-learning. In contrast to Hartman and Kiely as well as Longo and Saltmarsh, Bringle and Hatcher (2011) chose to focus intentionally on international service-learning (ISL), noting that "ISL is more than just service learning in a different setting because ISL's international setting provides new and unique opportunities for learning, especially in ways that contribute to the international education of students" (p. 19). This distinction between GSL and ISL mirrors that made by the American Council on Education's "Global Learning for All" project, wherein global refers to "the systems and phenomena that transcend national borders" and international to "the nations and their relationships" (Longo \& Saltmarsh, 2011, p. 73).

Although at first this may seem like a minor, primarily semantic difference between an emphasis on the global or international, the intentional distinction made by the authors mentioned previously in fact reflects a more fundamental question in the field of international/global service-learning (I/GSL): What is the role of place in these service-learning experiences? Is there something about service-learning in specific places, and in particular service-learning across national borders, that is separate (and separable) from what happens in those places?

Questioning the role of place in GSL experiences is grounded in the theoretical tradition of placebased education (PBE). Rooted primarily in the context of K-12 environmental education (Center for Place-based Learning, n.d.), PBE emphasizes the ways in which "places are powerfully pedagogical" (Gruenwald, 2008, p. 143). In practice, one of PBE's 10 principles asserts that "learning is grounded in and supports the development of a love for one's place" (Center for Place-based Learning, n.d., para. 2). Place-based educators often employ service-learning as one strategy for connecting students with local communities through experiential learning (Smith, 2002).

There are a number of similarities between the theory and practice of PBE and I/GSL. For example, both tend to focus on building partnerships between educational institutions and local communities, value sustainable development, and connect local learning to broader global issues (Center for Place-based Learning, n.d.; Hartman \& Kiely, 2014b). Not surprisingly, considering the use of 
service-learning as a typical pedagogical strategy within PBE, research on student outcomes of PBE parallels much of the service-learning literature. For example, PBE has been found to enhance academic achievement, foster engagement in and enthusiasm for learning, and promote active citizenship (PlaceBased Education Evaluation Collaborative, 2010).

The theoretical foundations of PBE are useful for understanding the ways in which different places may influence I/GSL experiences and in considering the importance of grounding I/GSL experiences in specific places. For example, although place-based education often emphasizes connections with students' own local communities, Gruenwald and Smith (2008) argued that PBE is key to understanding global relationships between and among communities, reflecting Hartman and Kiely's (2014b) assertion that GSL should help students connect their GSL experiences to broader global contexts. Hartman and Kiely also maintained that GSL should have an explicit focus on intercultural learning and that place-based educators should recognize that culture is dependent on place (Gruenwald, 2008). Thus, the places within which students learn about "common human dignity; self; culture; positionality; socio-economic, political, and environmental issues; power relations; and social responsibility" (Hartman \& Kiely, 2014b, p. 60) matter, helping to ground this learning in "concrete experience, experience that always takes place somewhere" (Gruenwald \& Smith, 2008, p. xxi).

\section{The Contested Role of Place in GSL}

As evidenced by the different definitions of ISL and GSL, the role of place in I/GSL experiences - and in particular the role of domestic or international places - has been contested. A number of service-learning scholars have argued that place is less relevant in service-learning experiences than what happens in those places. Perhaps the strongest critique of the relevance of international "place" in service-learning was provided by Jacoby (2009), who questioned the educational value of international places, asserting, "[The U.S.] is itself an international culture, and there are many opportunities for students to interact with individuals of widely varying backgrounds, cultures, customs, and beliefs" (pp. 100-101). Jacoby's assertion that students can learn about poverty, inequality, crime, and health care, among many other outcomes, from domestic service-learning experience is certainly supported in the literature. Domestic service-learning has been associated with a wide variety of positive outcomes, including development of awareness of stereotypes and social issues (Bowen, 2011; Jones \& Hill, 2001), civic commitment (Bowen, 2011; Keen \& Hall, 2009; Simons \& Cleary, 2006), and a greater understanding of diversity (Jones \& Hill, 2001; Simons \& Cleary, 2006).

In contrast to Jacoby (2009), Sutton (2011) argued that context and place are vital to servicelearning broadly, and in particular to ISL. She argued that "[ISL] programs must be framed by a deep understanding of the local context" (p. 125) and that "assuming service means the same thing regardless of location" (in addition to a number of other flaws of failing to recognize the importance of context) "creates a flimsy scaffold for ISL courses and research alike" (p. 126). Local context goes beyond understanding people and culture, and requires understanding the "intersection of politics, economics, environment, identity, and culture" (p. 136).

Other scholars have attempted to bridge the international and the local, focusing on the interconnections of issues among communities around the world. Like Hartman and Kiely (2014b), scholars in this camp have often argued for a focus on the "global" rather than the "international," attempting to strike a balance between recognizing the potential value of international experience. As Garcia and Longo (2013) asserted, "many of the goals for international service-learning can actually be met through community engagement at local levels" (p. 113). Rather than focusing exclusively on the international, Garcia and Longo advocated for an emphasis on "networks of relationships" and "ways of thinking" (p. 114) rather than location or nation-states.

Although there is a clear benefit to engaging in service-learning with culturally diverse communities within the United States - indeed, research on these types of experiences has shown that they can contribute to significant student learning about diversity and multiculturalism (Bowman \& Brandenberger, 2012; Denson, 2009; Gurin, Dey, Hurtado, \& Gurin, 2002) — there may be limits to what 
students can learn about the world through domestic service-learning. As Plater (2011) described, there is value in service-learning with culturally diverse and immigrant communities in the United States, but "unless [students] also engage the country of origin for the American community where the experience takes place ... the learning is constrained and perhaps not sufficient to develop international understanding" (p. 46).

All of these scholars would likely all agree on the importance of context in shaping students' experiences and learning, but their arguments about the relative value of international places to servicelearning experiences highlight an important debate within the field of service-learning. To what extent can a focus on high-quality service-learning experiences within students' own communities, or at least within the United States, achieve the goals of critical global citizenship and intercultural learning proposed by Hartman and Kiely (2014a, 2014b)? Or are international places "powerfully pedagogical" in ways that are fundamentally different than domestic places? Does, as Bringle and Hatcher (2011) argued, an "international setting [provide] new and unique opportunities for learning" (p. 19)?

\section{Comparing Domestic and International Experiences}

A small body of research comparing international and domestic experiences (mostly within the context of study abroad), or exploring domestic cross-cultural experiences, has pointed to the possible importance of international places in shaping students' experiences differently than domestic places do. Uehara (1986), for example, found that students who had studied abroad experienced significantly more culture shock upon returning to campus than did students who had travelled domestically. Couper (2001) also compared students who had studied abroad with those who had travelled domestically and found that study-abroad participants saw a much greater difference in their home communities after international travel than did non-study-abroad participants after domestic travel.

Not only may there be differences in the experiences of students who travel domestically and internationally, but there may also be differences in how students experience cross-cultural interactions within their home countries or abroad. Crawford (2008), for example, studied Finnish students who participated in a cross-cultural experience on their own campus through a "buddy" program with international students and found that the security of being at home led the Finnish students to take fewer risks in the cross-cultural interactions than they would have been forced to do if they were travelling or studying abroad. Although there is a broad body of literature supporting the importance of on-campus interactions with diverse peers (e.g., Bowman \& Brandenberger, 2012; Denson, 2009; Gurin et al., 2002) and of off-campus interactions with people from different cultures through study abroad (Crabtree, 2008), Crawford's findings point to the importance of place in shaping how students engage in and make meaning of these interactions.

\section{The Importance of Program}

The literature described earlier clearly establishes that place is a relevant consideration in students' experiences in both service-learning and study-abroad programs. However, as Niehaus and Crane (2013) argued, one of the reasons place is important is that students may have fundamentally different experiences in different places. So to what extent does the actual content of the I/GSL program matter? Research on service-learning and study abroad has provided empirical evidence supporting the importance of program features in facilitating student learning and development. The research on servicelearning has identified a number of key program features related to positive student outcomes. For instance, Eyler and Giles (1999) pointed to the importance of placement quality, written and discussion reflection, diversity, and community voice in academic service-learning experiences. More recently, Paige and Vande Berg (2012) reviewed the literature on specific interventions in study-abroad programs and found that cultural mentoring, engagement with host nationals, pre-departure orientation and postprogram reorientation, regular written reflection, and academic course content focusing on intercultural development all facilitate the development of intercultural competence in study-abroad experiences. 


\section{Place and/or Program?}

As described previously, prior research in service-learning and study abroad has established both that place matters and that program features matter. Yet, place and program are rarely considered together in a way that allows researchers to separate out the relative importance of each in shaping students' experiences. In some ways, these are of course inseparable. As Kiely (2005) noted, the ways in which students experience GSL are dependent upon the context in which these experiences occur. Much of the research in I/GSL, however, has been based in case studies of individual programs bound to individual places. As such, these studies have not interrogated how different places shape students' experiences differently. Even when research studies examine multiple programs across multiple locations, they often fail to compare locations or examine differences between domestic and international locations. Jones and colleagues (2012), for example, conducted a multiple case study of four short-term immersion programs and speculated that different trips in the study may have facilitated border crossing in different ways, but did not look at the role that an international or domestic trip location may have played in students' experiences of border crossing.

In one study specifically comparing international and domestic service-learning experiences, Niehaus and Crane (2013) found that students reported significantly different experiences depending on whether their service-learning took place within or outside of the United States, particularly regarding interactions with and learning from community and host-site staff, engagement of the community with the service project, their emotional reactions to the experience, and their pre-trip orientation and post-trip reorientation programs. Although Niehaus and Crane did not specifically examine differences in student outcomes, this study points to key differences in how students experience service-learning depending on location or place.

\section{The Present Study}

Considering the theoretical and empirical support for the role of place in service-learning experiences, the debate in the field over the value of international service-learning, and the lack of research examining the unique roles of place and program in students' learning, the purpose of this study was to explore the role of both place and program features in shaping how one particular type of servicelearning program, alternative breaks (ABs), influenced students' intentions to engage in future civic or international activity (i.e., volunteering or traveling abroad).

\section{The Context: Alternative Breaks}

Break Away (2014), a national organization that works with member campuses to promote best practices in $\mathrm{ABs}$, described an "alternative break" as:

a trip where a group of college students engage in direct service, typically for a week. Each trip has a focus on a particular social issue with exploration and immersion in that issue beginning long before the trip itself. Students educate themselves and each other, then do hands-on work with relevant organizations. (para. 1)

Research on ABs and similar types of programs has connected these experiences to a number of positive student outcomes, including perspective transformation (Jones et al., 2012; Kiely, 2004, 2005), spiritual or religious growth (Niehaus \& Rivera, 2016), understanding of the host community (Brakeley et al., 2014; Kiely, 2004), understanding of diversity and social justice (Niehaus \& Rivera, 2015; Niehaus, 2016), desire to adopt a more socially and/or environmentally conscious lifestyle (Jones et al., 2012; Kiely, 2004), critical perspectives on service and volunteerism (Brakeley et al., 2014; Kiely, 2004), integrative learning (Niehaus et al., 2017), and further civic engagement (Kiely, 2004; McElhaney, 1998). Although ABs are generally co-curricular, Eyler and Giles (1999) argued that "any program that attempts to link academic study with service can be characterized as service-learning" (p. 5); one of the defining features of $\mathrm{ABs}$ is the explicit attention to learning about a specific social issue in preparation for and during the trip itself. 


\section{Defining Place across National Borders}

Although there are many ways to consider the role of place in students' experiences with ABs, the purpose of this study was to explore the role of one particular dimension of place-international and domestic program location - in those experiences. As described earlier, the focus on international and domestic places responds to a definitional and theoretical debate in the field of I/GSL about the role of international place in these programs, but it is also positioned within a broader debate about the relative importance of national boundaries in an increasingly globalized world (e.g., Beck \& Sznaider, 2006; Shahjahan \& Kezar, 2013). As Stromquist (2002) summarized:

Some argue that as borders between countries become easier to cross, new transnational identities are being shaped and created. Others hold that there exist some complex and unavoidable relations between global capitalism and local identity formation. (p. 63)

If, as some have argued, these "new transnational identities" are more important than national identities, it is possible that students' concept of place and identity in service-learning experiences is independent of national boundaries - that is, an international program location would be indistinct from a culturally and environmentally different place within the United States. If, on the other hand, local and national identities are still relevant, or perhaps increasingly relevant despite an increasingly globalized and interconnected world, the distinction between international and domestic service-learning experiences may be profound in this regard.

\section{I/GSL as a Bridge between Civic and International Goals of Higher Education}

Although there is a vast array of outcomes associated with domestic service-learning, I/GSL, and $\mathrm{ABs}$, this study focused on the extent to which students reported that their $\mathrm{AB}$ experience influenced their intentions to volunteer or travel abroad. These outcomes reflect the way in which I/GSL is often positioned as bridging two parallel trends in higher education: internationalization and civic engagement (Crabtree, 2008; Garcia \& Longo, 2013; Jones et al., 2012; Plater, 2011). Additionally, as AB experiences are generally short-term (usually one week), it is important to consider how they may influence students' lives over the long term. Although examining students' intentions to volunteer or travel abroad does not directly measure long-term impact, multiple theories of behavior and commitment (e.g., Fishbein \& Ajzen, 1975; Lent, Brown, \& Hackett, 1994) posit that goals and intentions are important precursors to behaviors and commitments, and are thus important to study on their own.

\section{Methods}

In order to explore the role of both place and program features in how alternative-break programs influence students' intentions to volunteer or travel abroad, this study was guided by the following research questions:

1. What (if any) differences exist between students who participate in domestic and international $\mathrm{ABs}$ in terms of the extent to and ways in which they report that their $\mathrm{AB}$ experience influenced their intentions to volunteer or travel abroad?

2. To what extent are these differences between international and domestic AB participants explained by differences in other (non-place) features of the AB programs? In other words, to what extent do the specific features of $\mathrm{AB}$ programs mediate the relationship between program location and the perceived influence of the $\mathrm{AB}$ experience on students' intentions to volunteer or travel abroad?

\section{Data and Participants}

Data for this study came from the National Survey of Alternative Breaks (NSAB), which was developed based on the existing literature on $\mathrm{ABs}$, domestic and international service-learning, and study abroad. The instrument was reviewed by experts in the AB field and in survey research more broadly to ensure face validity and appropriate survey design, and then piloted by 131 students at nine institutions who participated in alternative break trips during the winter of 2011. Data for the full NSAB were 
collected via an IRB-approved online survey within a few weeks of students' return to campus from ABs in the spring of 2011.

In order to ensure a wide variety of institutions in the sample, the researchers obtained from Break Away a list of all U.S. colleges and universities with AB programs. From this list, researchers took a random stratified sample of institutions based on institution type and size, intentionally oversampling large research universities to ensure adequate sample size; they then contacted a gatekeeper (usually the $\mathrm{AB}$ coordinator) at each institution for assistance in recruiting participants. The gatekeeper was asked to send an e-mail invitation with a link to the online survey to all students who participated in ABs during the spring of 2011 at that institution.

In total, 2,187 students representing 443 separate $A B$ trips at 97 colleges and universities responded to the survey (an overall student response rate of $35 \%$ based on the number of $A B$ participants reported by gatekeepers at each institution). The respondents were predominantly female (79\%) and White (73\%), with smaller numbers of students identifying as Asian/Pacific Islander (9\%), Multiracial (6\%), African American (6\%), Hispanic (5\%), or another racial/ethnic group (2\%). There was no known information on the demographic makeup of $\mathrm{AB}$ participants nationally to determine the representativeness of this sample. However, the racial and gender composition of the sample was similar to Skendall's (2012) sample of participants in short-term service immersions (including ABs) from a national survey of college students; a comparison of the two samples indicated that the NSAB data might have had a slight overrepresentation of students who identified as White and female.

A slight majority (55\%) of participants attended doctoral/research universities, with $28 \%$ attending masters-level institutions, $16 \%$ attending baccalaureate-level institutions, and $1 \%$ attending associates-level institutions. The majority participated in domestic programs (84\%), including trips to New Orleans (11\%), Atlanta (4\%), and Washington, DC (3\%), among many others. The most popular international destinations included Jamaica (3\%), Guatemala (2\%), the Dominican Republic (2\%), and Honduras (1\%).

\section{Variables}

The main outcome variables for this study came from two individual items on the survey; students were asked to report the extent to which they felt that their $\mathrm{AB}$ experience influenced their plans to volunteer or travel abroad. These items were both measured on a scale of 0 to 4 , with 0 representing "not at all" and 4 representing "a great deal." In order to provide more depth of description about the ways in which students perceived that their $\mathrm{AB}$ experience influenced their lives in these two ways, we also examined a number of follow-up questions on the survey. Each respondent who rated an item above "not at all" in the initial items saw a series of follow-up questions. With regard to their intentions to volunteer, students were asked whether they planned to volunteer more than, less than, or about the same as prior to their $\mathrm{AB}$. Regarding their intentions to travel internationally, students were asked to indicate the extent to which they agreed or disagreed $(1=$ strongly disagree, $2=$ disagree, $3=$ neither agree nor disagree, $4=$ agree, 5 = strongly agree) that their $\mathrm{AB}$ experience inspired a new desire to travel internationally, reinforced an existing desire to travel internationally, made them more confident in travelling internationally, and made them want to focus future international travel on learning more about people and cultures. Students were also given the opportunity to provide written comments about how else, if at all, their $\mathrm{AB}$ experience influenced their plans to volunteer or travel internationally.

The program location was measured by asking students to report whether they considered the location of their program to be local (in the same city or town as their college or university), domestic (away from their college or university but within the United States), or international. Since this study focused on the difference between international and domestic ABs, and all students attended colleges and universities within the United States, "local" ABs were considered to be "domestic."

Of interest in this study were program features found in earlier research to be significant predictors of each outcome variable (Niehaus, 2012) and to vary significantly based on program location (Niehaus \& Crane, 2013). These included community engagement, community interaction, community learning, staff learning, social issues, journaling, emotional intensity, orientation, and reorientation. All 
variables were measured using either individual items or composite measures from the NSAB survey. Composite measures were developed using exploratory principle components analysis; individual items, factor loadings, and reliability information for composite measures are provided in Table 1.

Table 1. Program Variables

\begin{tabular}{|c|c|c|}
\hline Variable & Definition & $\begin{array}{l}\text { Factor } \\
\text { Loadings }\end{array}$ \\
\hline \multirow{6}{*}{$\begin{array}{l}\text { Community } \\
\text { Engagement } \\
(\text { alpha }=.868)\end{array}$} & The extent to which $\ldots .(1=$ not at all, $5=$ very much $)$ & \\
\hline & Students worked directly with the community. & .848 \\
\hline & The community was involved in the execution of the project. & .857 \\
\hline & The community was involved in the design of the project. & .822 \\
\hline & $\begin{array}{l}\text { Students developed relationships with people in the community } \\
\text { being served. }\end{array}$ & .797 \\
\hline & Students met community-identified needs. & .719 \\
\hline $\begin{array}{l}\text { Emotional } \\
\text { Challenge }\end{array}$ & $\begin{array}{l}\text { The extent to which students felt they were emotionally challenged by } \\
\text { their experience. }(1=\text { not at all, } 5=\text { very much })\end{array}$ & \\
\hline $\begin{array}{l}\text { Community } \\
\text { Interaction }\end{array}$ & $\begin{array}{l}\text { The frequency with which students reported interacting with community } \\
\text { members. }(1=\text { never, } 2=\text { once or twice during the week, } 3=\text { more than } \\
\text { once or twice but less than every day, } 4=\text { once a day, } 5=\text { more than } \\
\text { once a day) }\end{array}$ & \\
\hline $\begin{array}{l}\text { Community } \\
\text { Learning }\end{array}$ & $\begin{array}{l}\text { The amount students reported learning from community members. }(1= \\
\text { nothing, } 5 \text { = quite a lot) }\end{array}$ & \\
\hline Staff Learning & $\begin{array}{l}\text { The amount students reported learning from host site staff. }(1=\text { nothing, } \\
5=\text { quite a lot })\end{array}$ & \\
\hline \multirow[t]{6}{*}{$\begin{array}{l}\text { Social Issues } \\
(\text { alpha }=.805)\end{array}$} & $\begin{array}{l}\text { The extent to which students agreed that } \ldots(1=\text { strongly disagree, } 5= \\
\text { strongly agree) }\end{array}$ & \\
\hline & $\begin{array}{l}\text { I was able to see the larger context of the social issue addressed by } \\
\text { my } 2011 \text { AB trip. }\end{array}$ & .819 \\
\hline & $\begin{array}{l}\text { My } 2011 \mathrm{AB} \text { experience allowed me to come to a greater } \\
\text { understanding of the social issue being addressed by my trip. }\end{array}$ & .824 \\
\hline & $\begin{array}{l}\text { My } 2011 \text { AB trip helped me connect real people to the trip social } \\
\text { issue. }\end{array}$ & .786 \\
\hline & $\begin{array}{l}\text { I was able to connect my } 2011 \text { AB trip to other things I have learned } \\
\text { outside the classroom. }\end{array}$ & 670 \\
\hline & $\begin{array}{l}\text { My } 2011 \mathrm{AB} \text { experience allowed me to come to a greater } \\
\text { understanding of the region where my trip took place. }\end{array}$ & .659 \\
\hline
\end{tabular}

\begin{tabular}{ll} 
Journaling & $\begin{array}{l}\text { How frequently students wrote in an individual journal. }(1=\text { never, } 2= \\
\text { once or twice during the week, } 3=\text { more than once or twice but less } \\
\text { than every day, } 4=\text { once a day, } 5=\text { more than once a day })\end{array}$ \\
\hline $\begin{array}{l}\text { Emotional } \\
\text { Intensity }\end{array}$ & $\begin{array}{l}\text { The extent to which students agreed that } \ldots(1=\text { strongly disagree, } 5= \\
\text { strongly agree })\end{array}$
\end{tabular}




\begin{tabular}{|c|c|c|}
\hline Variable & Definition & $\begin{array}{c}\text { Factor } \\
\text { Loadings }\end{array}$ \\
\hline \multirow[t]{4}{*}{$(\mathrm{alpha}=.760)$} & My 2011 Alternative Spring Break trip was an intense experience. & .841 \\
\hline & $\begin{array}{l}\text { I experienced strong emotions during my } 2011 \text { Alternative Spring } \\
\text { Break experience. }\end{array}$ & .804 \\
\hline & $\begin{array}{l}\text { My } 2011 \text { Alternative Spring Break experience allowed me to } \\
\text { experience something totally new. }\end{array}$ & .729 \\
\hline & $\begin{array}{l}\text { My } 2011 \text { Alternative Spring Break experience caused me to re- } \\
\text { examine my beliefs about the root causes of social issues. }\end{array}$ & .698 \\
\hline Orientation & $\begin{array}{l}\text { The total number of activities in which students reported engaging prior } \\
\text { to their trip (out of } 7 \text { possible choices), including: learn about the } \\
\text { mission and objectives of the organization with whom they were } \\
\text { working during their AB trip; learn about the history or culture of the } \\
\text { location they travelled to; receive training in skills that would be } \\
\text { necessary for the project they would work on; learn about the social } \\
\text { issue being addressed by their trip; discuss culture shock or cross- } \\
\text { cultural communication skills. }\end{array}$ & \\
\hline Reorientation & $\begin{array}{l}\text { The total number of activities in which students reported engaging after } \\
\text { their trip (out of } 8 \text { possible choices), including: discuss their } \\
\text { experiences with the other students on the trip, other students from their } \\
\text { college or university who went on different trips, or others on their } \\
\text { campus who were not part of the AB program; or having been provided } \\
\text { with information on reverse culture shock or encouraged to find ways to } \\
\text { engage in future community service or service-learning activities, or to } \\
\text { find other ways to build on their AB experience, either by some } \\
\text { affiliated or unaffiliated with their AB program. }\end{array}$ & \\
\hline
\end{tabular}

\section{Data Analysis}

The data analysis for this study proceeded in three steps. First, we calculated basic descriptive statistics (frequencies and means) on the main outcome measures and follow-up questions described earlier to identify the extent to which and ways in which students overall reported that their $\mathrm{AB}$ experience influenced their plans to volunteer and travel internationally. To further explore the ways in which students perceived that their AB influenced their plans to volunteer and travel internationally, we examined participant responses to these two open-ended questions. We first engaged in open coding of the responses, generating a list of broad themes (Yin, 2011). We then used the themes to code responses in a second review of these data. During this phase, inductive coding was also employed in an effort to identify emerging themes (Miles, Huberman, \& Saldana, 2014). All responses were reviewed again to ensure they were coded appropriately given the additional themes that emerged during the coding process.

Second, in order to identify potential differences between international and domestic AB participants regarding the influence of the $\mathrm{AB}$ on their intentions to volunteer or travel internationally, we calculated t-tests for all closed-ended items described earlier. We then used Pearson chi-square tests to determine whether there were significant differences in the number of international and domestic trip participants who reflected different themes in their responses to open-ended items.

Finally, to determine whether or not the difference between international and domestic AB participants in the main outcome measures (i.e., the extent to which participants reported that their $\mathrm{AB}$ influenced their intentions to volunteer or travel abroad) were explained by differences in other (non- 
place) features of the $\mathrm{AB}$ programs, we conducted a multi-level mediation analysis. In their seminal work on this type of analysis, Baron and Kenny (1986) explained that "a given variable may be said to function as a mediator to the extent that it accounts for the relation between the predictor and the criterion....

[M] ediators speak to how or why such effects occur" (p. 1176). In other words, does the program location influence outcomes because the program location actually influences specific program features, which in turn influence outcomes?

Figures 1 and 2 illustrate a possible mediation effect in the context of AB programs. Figure 1 depicts an unmediated relationship (c) between program location and outcomes, while Figure 2 shows a mediated relationship $\left(\mathrm{c}^{\prime}\right)$ between program location and outcomes. Mediation is also sometimes discussed in terms of direct and indirect effects; in Figure 2, the direct effect of program location on outcomes is represented by c', while the indirect relationship is represented by the combination of paths a and b. Baron and Kenny (1986) held that the strongest evidence of mediation is when there is only an indirect effect (paths $a$ and $b$ are significant) with the direct effect reduced to zero (path $c^{\prime}$ is not significant), but noted the possibility of partial mediation (paths $a, b$ and $c^{\prime}$ are all significant, but $c^{\prime}$ has been significantly reduced from c).



Figure 1. Unmediated relationship between program location and outcomes.

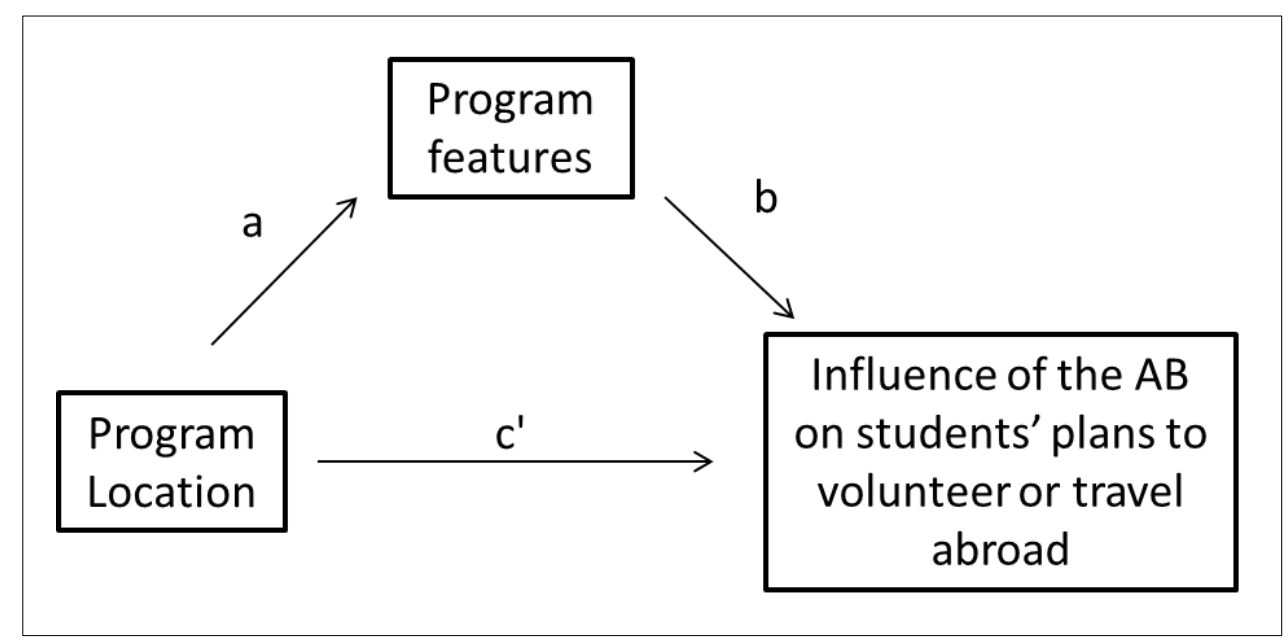

Figure 2. Possible mediation of relationship between program location and outcomes.

Baron and Kenny (1986) discussed mediation analysis within a multiple linear regression framework, but due to the nested nature of the NSAB data, hierarchical linear modeling (HLM) was a more appropriate analytic technique (Raudenbush \& Bryk, 2002). As this study focused on the specific program features that may mediate the relationship between program location and outcomes, and because prior research using the NSAB dataset has found relatively little variance in each outcome explicable at the institution level (Niehaus, 2012), this analysis only utilized a two-level model (i.e., the student and the program levels). 
The first step in our analysis was to calculate the intraclass correlation (ICC), or the amount of variance that could be accounted for at each level of analysis, using a random effects ANOVA model. Then, following the Baron and Kenny (1986) method, as adapted to HLM by Zhang, Zyphur, and Preacher (2009), we conducted a basic HLM analysis to determine if international program location alone predicted each of the outcomes. Next, where a significant direct effect of the program location on each outcome existed, we identified the program features that might mediate that relationship by examining the overlap between Niehaus's (2012) analysis of the program features that significantly predicted each outcome (path b in Figure 2), and Niehaus and Crane's (2013) analysis of the program features that significantly varied based on program location (path a in Figure 2); program features that met both of these criteria for an individual outcome were included as possible mediators for that outcome. For the influence of the $\mathrm{AB}$ experience on students' intentions to volunteer, potential mediators included community interaction, community learning, social issues, journaling, emotional intensity, and reorientation. For the influence of the $\mathrm{AB}$ on students' intentions to travel internationally, potential mediators included community engagement, community interaction, journaling, orientation, and reorientation.

Third, we conducted an HLM analysis with both the program location and possible mediators as predictors of each outcome. Finally, as recommended by Baron and Kenny (1986), we tested the significance of the mediation effect by calculating a z-score for each individual mediator, following Zhang et al.'s (2009) adaptation of the Sobel product-of-coefficients method, converting the $z$-score for each mediator to a $p$-value to determine whether each individual program feature significantly mediated the relationship between program location and outcomes at the $.05, .01$, and .001 levels.

\section{Limitations}

Before discussing the results, it is important to first note a few key limitations of this study. First, the outcomes used in this study focus on students' plans to volunteer or travel abroad. Although these outcomes reflect the way in which I/GSL bridges internationalization and civic engagement (Crabtree, 2008; Garcia \& Longo, 2013; Jones et al., 2012; Plater, 2011) and may point to longer-term outcomes, they may not be stated goals of AB programs. Similarly, these outcomes focus on behavioral goals and intentions, as opposed to actual changes in behavior. Many (e.g., Kiely, 2005) have noted that intentions do not always lead to actions. It is possible that immediately after an intense experience like an AB trip, students may think that the experience has changed their lives in profound ways but may never actually change their behavior in any meaningful way.

Second, there are a number of limitations in the ways in which place and program features were measured in the NSAB. For example, the orientation and reorientation composite variables are summative and thus do not take into account differences in different types of orientation and reorientation activities. We also only considered domestic and international trip locations as a measure of "place" in students' $\mathrm{AB}$ experiences. Although this addresses a key question in the field of I/GSL, there are many other dimensions of place that may be relevant to students' experiences and deserve further research.

Third, our sample comprised predominantly White and female respondents. Although this is reasonably consistent with the population of students most likely to participate in ABs (see Skendall, 2012, for example), our findings may not be generalizable to all AB participants. We also did not explore how gender, race, or other demographic variables might moderate the relationships explored in this study. Future research should examine the ways in which different students may experience ABs differently based on their various intersecting identities.

Finally, although this study identified differences between international and domestic trips and if those differences were accounted for by differences in program features, it did not identify why this was the case. As Niehaus and Crane (2013) noted, it is possible that there is something inherently different about an international versus a domestic experience, but it is also possible that practitioners working with international trips are more intentional about incorporating best practices. 


\section{Results \\ Overall Influence of Both Domestic and International AB Experiences}

To examine the extent to and ways in which students reported that their $\mathrm{AB}$ experiences influenced their plans to volunteer or travel abroad overall, we calculated frequencies and means for each closed-ended question and identified overarching themes in responses to the open-ended items. Overall, we found that participants reported a high level of influence of their AB experience on both their intentions to volunteer and to travel internationally-on a scale of 0 to 4 (with 0 indicating "not at all" and 4 indicating "quite a lot"), $83.5 \%$ of participants indicated a substantial influence of the AB on their intentions to volunteer (responding with either a 3 or 4 ; mean $=3.30$ ), and $53.6 \%$ indicated a substantial influence of the $\mathrm{AB}$ on their intentions to travel internationally (mean = 2.38).

In both the closed- and open-ended follow-up questions, participants reported that their $\mathrm{AB}$ experiences influenced these plans in a number of ways. Regarding their intentions to volunteer, $69.3 \%$ indicated that they planned to volunteer more than they had planned to do prior to their AB experience. We examined participant responses $(N=843)$ to the open-ended question about how the AB experience affected future volunteer plans for domestic trip participants $(N=698)$ and international trip participants $(N=145)$. There were a number of common themes across responses from both international and domestic trip participants, such as recognizing the importance of helping others and their ability to make a difference through volunteer work. One domestic participant reflected, "I just saw how each day I at least affected one person's life at that moment in time, and that was enough for me to want to help everyone that I can." Similarly, an international trip participant felt that the experience "has given me a passion to serve others and to see the joy that serving them can bring."

Participants explained their commitment to particular service issues and plans to pursue volunteer work in relation to those issues. One domestic trip participant commented, "I see issues related to social justice in a new light and hope to seek volunteer opportunities to develop this interest," while an international participant noted, "It made me more interested in Mexico/American relations and increased my desire to work in fields relating to issues of the border." Participants also reflected on ways their experiences changed their views of service. One domestic trip participant described, "It changed my perception of what volunteering actually is and how it can help you grow as a person." Likewise, an international trip participant asserted, "This trip made me want to volunteer more and to appreciate the life that I have. It changed the way I look at life." A number of domestic and international trip participants also noted that the experience gave them more insight into ways they could volunteer or different organizations they could connect with to do so. For example, a domestic participant explained, "I have always been active with volunteering in my community. However, my experience working in a charter school ... made me want to explore more volunteer opportunities in the education system." An international participant shared, "Because of ASB, I have plans to join the Peace Corps."

With regard to their plans to travel internationally, in the closed-ended questions, $28.4 \%$ of participants agreed or strongly agreed that their alternative break inspired a new desire to travel internationally, $40.3 \%$ agreed or strongly agreed that their AB reinforced an existing desire to travel internationally, $41.8 \%$ agreed or strongly agreed that their $\mathrm{AB}$ experience made them more confident travelling internationally, and $42.2 \%$ of participants agreed or strongly agreed that their $A B$ made them want to focus future travel on learning more about people and cultures. In examining the open-ended question, comparable numbers of respondents from both international and domestic trips noted that their $\mathrm{AB}$ increased their confidence in their ability to travel in unfamiliar circumstances. A domestic trip participant reflected:

My trip was technically domestic, but in some ways it felt international since I went to a Native American reservation. The experience made me more confident in traveling to such places and reinforced a desire to learn more about different peoples and cultures.

One international trip participant noted, "I know that I can better handle travelling, and I know more how many amazing things are out in the world to see." Participants in international and domestic trips also expressed their desire for more cultural experiences and to meet new people. For instance, one domestic 
participant recalled, "Seeing how different the culture just in the South of our own country was, I want to experience what other countries have to offer and learn about their lifestyles as well." Similarly, one of the international participants commented, "ASB made me see a different culture which was amazing to experience and I would love to travel to other countries and see more."

\section{Differences between International and Domestic Trip Participants}

To identify whether or not there were differences between students who participated in domestic and international ABs, we used t-tests to test for significant differences in students' responses to closedended questions and chi-squared to test for significant differences in how commonly we identified particular themes in students' responses to the open-ended items (see Table 2). It is important to note that while the results of the tests pointed to interesting group differences, we cannot assume the results imply causation. Nonetheless, the findings discussed here shed light on notable differences identified in the analysis.

Table 2. Significant Differences between International and Domestic Participants: Mean Responses to Close-Ended Items

\begin{tabular}{lcc}
\hline Closed-Ended Item & Domestic & International \\
\hline Influence of the AB on participants' intentions or plans to volunteer. & 3.28 & 3.40 \\
Influence of the AB on participants' intentions or plans to travel abroad. & 2.20 & 3.25 \\
AB reinforced participants' existing desires to travel internationally. & 3.84 & 4.36 \\
AB inspired a new desire to travel internationally. & 3.29 & 3.66 \\
AB made participants want to focus future international travel on learning & 3.80 & 4.33 \\
more about people and cultures. & 3.55 & 4.26 \\
AB made participants more confident in travelling internationally. & \\
\hline
\end{tabular}

Note.

$\Delta$ Items based on a 0 (not at all) to 4 (quite a lot) scale.

- Items based on a 1 (strongly disagree) to 5 (strongly agree) scale.

The results of the tests revealed that although students overall reported a strong influence of their $\mathrm{AB}$ experiences on their intentions to both volunteer and travel internationally, there were a number of differences between students who participated in domestic and international ABs. Regarding their intentions to volunteer, domestic trip participants reported a significantly lower level of overall influence of the $\mathrm{AB}$ on their intentions or plans to volunteer (mean $=3.28$ ) than international trip participants (mean $=3.40 ; t=-2.294, p=.022$ ), although the actual difference between the two groups was small; on a scale of 0 to $4(0=$ not at all, $4=$ quite a lot $), 83.1 \%$ of students on domestic trips and $87.2 \%$ of students on international trips answered 3 or 4 .

Although the two groups described the changes to their approach to volunteering in similar ways, many of their responses differed in regard to where they planned to serve in the future; these comments seemed to reflect their AB location. While both groups included participants who recognized domestic and international needs, the international participants more frequently expressed plans to volunteer outside of the United States or with international issues than domestic participants $\left(\chi^{2}=57.511, d f=1, p\right.$ $<.001)$. One international trip participant reflected:

I knew that I wanted to use my skills as an RN to help those people.... After attending my spring break trip, I now want to travel to other countries using my skills as an RN to help women and children who need it more than ever! 
On the other hand, domestic trip participants more frequently expressed plans to volunteer within the United States $\left(\chi^{2}=9.07, d f=1, p=.003\right)$-both generally as well as within their own communities. For example, one domestic participant stated:

Before break I really wanted to do volunteer work outside of the United States, but after this experience I have realized that you don't have to go outside of the country to have a great volunteer experience. It also taught me that I can help a lot in my own community and the surrounding areas.

There were also significant differences between the overall extent to which domestic and international trip participants believed the $\mathrm{AB}$ experience influenced their intentions or plans to travel internationally $(t=-14.950, p<.001)$; international trip participants reported that the AB influenced their plans more (mean $=3.25)$ than domestic trip participants (mean $=2.20)$. On a scale of 0 to $4(0=$ not at all, $4=$ quite a lot), $47.4 \%$ of students on domestic trips and $86.0 \%$ of students on international trips answered 3 or 4 .

Students who participated in international ABs also indicated a higher level of agreement with a number of the closed-ended follow-up questions. International participants agreed more strongly that their experiences reinforced their existing desires to travel internationally (mean $=4.36)$ than did domestic participants (mean $=3.84 ; t=-10.227, p=<.001$ ). International participants also agreed more strongly than domestic participants that their $\mathrm{AB}$ experience inspired a new desire to travel internationally (international mean $=3.66$, domestic mean $=3.29 ; t=-5.887, p=<.001$ ); that their experience made them want to focus future international travel on learning more about people and cultures (international mean $=$ 4.33, domestic mean $=3.80 ; t=-10.525, p=<.001$ ); and that the $\mathrm{AB}$ made them more confident in travelling internationally (international mean $=4.26$, domestic mean $=3.55 ; t=-14.376, p=<.001$ ).

There were also a number of differences in the themes in participants' responses to the openended item regarding the ways in which their $\mathrm{AB}$ experience influenced their plans to travel internationally. International trip participants more frequently mentioned plans to travel abroad within their responses than domestic students $\left(\chi^{2}=13.153, d f=1, p=<.001\right)$. An international trip participant shared:

I always knew I wanted to travel internationally, but travelling to Guatemala really made me look at Central and South America as possible destinations. Before my desired destinations were mostly in Europe, but now I have a more diverse and expanded view of where I want to travel. Perhaps even more interesting was that domestic trip participants frequently expressed that because their trip was within the United States, the question did not apply to them. One participant asserted, "I attended a domestic Alt Break trip, so [it] has no real application to my desire to travel internationally." Another individual stated, "Our trip was more nationally focused so I did not think much about traveling internationally." This was not the case for every domestic participant; for instance, one person reflected, "After doing this, I realized how much I want to go and travel to third world countries and volunteer there." The varied responses shed light on how the AB experience affected participants' plans in different ways.

\section{Influence of Program Features}

To identify whether differences between international and domestic trip participants were related to program features independent of trip location (i.e., are these differences due to presumably changeable program features rather than trip location?), we conducted a multi-level mediation analysis for the two overall outcomes measures: the extent to which students reported that their AB influenced their intentions to volunteer or to travel internationally. The intraclass correlation (ICC) for the influence of the AB on students' intentions to volunteer was .088, and for the influence of the AB on students' intentions to travel abroad the ICC was .127. The mediation analysis showed that after accounting for program features, there was no remaining influence of location on the influence of the AB on students' plans to volunteer $\left(c^{\prime}=\right.$ $.042, p=.537)$; the program features completely mediated the relationship between location and this outcome. In other words, there was no direct effect of program location on this outcome; there was only an indirect effect, in that program location was related to differences in program features, which in turn 
were related to differences in the influence of the $\mathrm{AB}$ experience on students' intentions to volunteer. Specifically, location-volunteer relationship was significantly mediated by the amount students reported learning from community members $(b=.218, z=3.772, p<.001)$, the extent to which they were able to connect their experiences to broader social issues $(b=.067, z=2.597, p=.009)$, the frequency with which they wrote in an individual journal $(b=.073, z=2.981, p=.003)$, and the emotional intensity of the experience $(b=.034, z=2.648, p=.008)$.

The pattern of mediation was slightly different regarding the relationship between trip location and the influence of the $\mathrm{AB}$ experience on students' plans to travel internationally. Even after adding in a variety of program features, the international program location was still a significant, positive predictor of the influence of the AB on students' plans to travel internationally $\left(c^{\prime}=1.002, p<.001\right)$. However, after testing for a significant mediation effect, we found that the effect of the location on this outcome was partially mediated by the program features. There was both a direct effect of the program location on the influence of the $\mathrm{AB}$ experience on students' plans to travel internationally, and an indirect effect - that is, the program location had an effect on program features, which in turn had an effect on this outcome. The relationship between the international location and the influence on students' plans to travel abroad was significantly, partially mediated by the extent to which community members were engaged in the service activities $(b=.046, z=3.825, p<.001)$, the frequency with which students interacted with community members $(b=-.148, z=-3.042, p=.002)$, the amount students reported learning from community members $(b=.260, z=3.253, p=.001)$, and the frequency with which students wrote in an individual journal $(b=.077, z=2.109, p=.035)$.

\section{Discussion and Implications}

Consistent with the prior literature on alternative breaks (e.g., Brakeley et al., 2014; Jones et al., 2012; Niehaus, 2012; Niehaus \& Rivera, 2016), the findings from this study point to the potential for these experiences to influence students' lives and goals in profound ways. This study makes a unique contribution to the literature on international higher education, and on international service-learning specifically, by examining the role of place in students' domestic and international experiences and highlighting the nuances that exist among the outcomes of these experiences. Because $\mathrm{AB}$ experiences share similar structures and take place in domestic and international settings, this study was uniquely positioned to explore comparisons among these experiences. In particular, the use of place-based education as a theoretical framework for understanding these experiences provided a foundation for exploring the role of domestic and international places in shaping students' experiences.

While the design of the study limited our ability to infer causation, our findings support the assertion that place matters (Bringle \& Hatcher, 2011; Center for Place-Based Learning, n.d.; Gruenwald, 2008; Gruenwald \& Smith, 2008; Plater, 2011; Sutton, 2011) in shaping student experiences and outcomes, particularly in relation to the places students focus on when shaping their future plans to volunteer and travel. Perhaps not surprisingly, students who participated in domestic ABs were more likely to want to volunteer and travel domestically in the future, and students who participated in international ABs were more likely to want to volunteer and travel internationally in the future. Contrary to assertions that domestic service-learning and study-away experiences are fundamentally the same as international experiences (e.g., Jacoby, 2009; Sobania, 2015), our findings suggest that the place where an $\mathrm{AB}$ experience takes place does seem to influence how students perceive these experiences influencing their lives.

There were also significant differences in the extent to which students reported that their $A B$ influenced their future plans - a small difference when it came to their plans to volunteer, a larger difference when it came to their plans to travel internationally. Importantly, though, the small difference in the influence of the AB on students' plans to volunteer was completely mediated by the extent to which students were able to learn from community members and connect their experience to broader social issues, how frequently students wrote in an individual journal, and how emotionally intense they felt their $\mathrm{AB}$ experience was. This finding points to a number of implications for practice, particularly for those 
practitioners whose goals are more service- or civic-oriented in nature. If the goal of an $\mathrm{AB}$ is to foster civic engagement and commitment to service, domestic experiences that are emotionally intense and focus on enhancing community interactions, making connections to broader social issues, and encouraging students to engage in reflective writing are likely to be just as effective at achieving this goal as international programs. In fact, the finding that students who participated in domestic ABs were more likely to discuss volunteering in their own communities might point to an advantage of domestic programs if the goal is to encourage students to connect their AB learning back to issues happening back home.

In contrast to the influence of the $\mathrm{AB}$ experience on students' plans to volunteer, there was a much greater difference between international and domestic trip participants in their reports of the influence of the $\mathrm{AB}$ on their plans to travel internationally. This difference was only partially mediated by features of the $\mathrm{AB}$ program itself. As $\mathrm{ABs}$ and other forms of I/GSL are often positioned as achieving the goals of both civic engagement and internationalization (Crabtree, 2008; Garcia \& Longo, 2013; Jones et al., 2012; Plater, 2011), this finding has key implications for practice. Although domestic service-learning can obviously achieve a number of positive outcomes related to cross-cultural learning (e.g., Bowen, 2011; Jones \& Hill, 2001; Simons \& Cleary, 2006), these programs may be less effective at truly teaching students about global and international issues than experiences in which students actually travel internationally. Students who participated in international ABs planned to be significantly more internationally engaged than did domestic $\mathrm{AB}$ participants, as reflected in their answers to the closedended questions and in how they discussed their plans to travel and volunteer after their AB experiences ended. If the goal is to enhance international engagement, there may be no substitute for an international experience.

Although this study contributes to the broader discussion on the relative importance or value of international versus domestic experience, it also leaves a number of questions unanswered. The scope of the NSAB allows for a big-picture view of what many different students are experiencing in many different types of $\mathrm{AB}$ programs, but the large-scale, quantitative nature of the study did not allow for an understanding of the nuances of students' experiences. Future research should focus on gaining a more insight into how students interact with the places in which their ABs take place and how students make meaning of those places. Are there ways in which students make meaning of experiences outside of the United States. in fundamentally different ways than the ways in which they make meaning of experiences within the United States? The large-scale nature of this study also did not allow for an examination of the ways, if any, that educators working with ABs might facilitate students' abilities to connect domestic experiences to broader international or global issues — an important area for future research.

\section{Conclusions}

This study builds on the existing research on alternative breaks and global service-learning, providing one more piece of the puzzle in determining whether or not international service-learning is fundamentally different from domestic service-learning. In examining students' perceptions of the influence of the $\mathrm{AB}$ experience on their lives, we found that the answer to this question was yes, no, and maybe - ultimately it depends on the goals of the program. If the program's goals are international in nature (e.g., to encourage interest in future international study or travel), then yes, the direct effect of an international $\mathrm{AB}$ program on these outcomes, independent of the specific program features, suggests that location may matter. Although there are clearly phenomenal domestic $\mathrm{AB}$ and other service-learning experiences that lead to significant student outcomes, and some domestic programs are likely more effective than some international ones, this study shows that, in general, students on international ABs (and possibly other service-learning programs) may in fact have different experiences, and those varied experiences can lead to differences in students' perceptions of the influence of the $A B$ experience on their lives. 


\section{Author Note}

Elizabeth K. Niehaus, Educational Administration, University of Nebraska-Lincoln; Crystal E. Garcia, Educational Foundations, Leadership, and Technology, Auburn University.

Correspondence regarding this article should be addressed to Elizabeth K. Niehaus, Assistant Professor, Educational Administration, University of Nebraska-Lincoln, Teachers College Hall 133, Lincoln, NE 68588. Phone: (402) 472-4236. E-mail: eniehaus@unl.edu

\section{References}

Altbach, P. G. (2004). Globalization and the university: Myths and realities in an unequal world. Tertiary Education and Management, 10, 3-25.

American Council on Education. (2002). Beyond September 11: A comprehensive national policy on international education. Washington, DC: Author. Retrieved from http://www.acenet.edu/bookstore/pdf/2002 beyond 911.pdf

Baron, R. M., \& Kenny, D. A. (1986). The moderator-mediator variable distinction in social psychological research: Conceptual, strategic, and statistical considerations. Journal of Personality and Social Psychology, 51(6), 1173-1182.

Beck, U., \& Sznaider, N. (2006). Unpacking cosmopolitanism for the social sciences: A research agenda. British Journal of Sociology, 57(1), 1-23.

Bowen, G. A. (2011). Fostering college students' civic commitment through alternative breaks. Journal for Civic Commitment, 16, 1-13.

Bowman, N. A., \& Brandenberger, J. W. (2012). Experiencing the unexpected: Toward a model of college diversity experiences and attitude change. , Review of Higher Education, 35(2), 179-205.

Brakeley, M., Camo-Biogradlija, J., DiVivo-Brassaw, G., Giacobozzi, S., Hazleton, A., Holder, C., ... Viramontes, J. (2014). The Haiti Compact 2014: Four years later. Retrieved from http://www.alternativebreaks.org/wp-content/uploads/2014/06/HaitiCompact 4YearReport highres.pdf

Break Away. (2014). Movement lexicon. Retrieved from http://www.alternativebreaks.org/ learn/lexicon

Bringle, R. G., \& Hatcher, J. A. (2011). International service learning. In R. Bringle, J. Hatcher, \& S. Jones (Eds.), International service learning: Conceptual frameworks and research (pp. 3-28). Sterling, VA: Stylus.

Center for Place-based Learning and Community Engagement. (n.d.). Principles of place-based education. Retrieved from http://www.promiseofplace.org/what-is-pbe/principles-of-place-based-education

Couper, G. E. (2001). The psychology of travel: A theoretical analysis of how study abroad and positive regression affect personal growth (Unpublished doctoral dissertation). Northcentral University, Scottsdale, AZ.

Crabtree, R. D. (2008). Theoretical foundations for international service-learning. Michigan Journal of Community Service Learning, 15(1), 18-36.

De Wit, H. (2002). Internationalization of higher education in the United States and Europe. Westport, CT: Greenwood.

Denson, N. (2009). Do curricular and cocurricular diversity activities influence racial bias? A metaanalysis. Review of Educational Research, 79(2), 805-838.

Eyler, J., \& Giles, D. E. (1999). Where's the learning in service-learning? San Francisco: Jossey-Bass.

Fishbein, M., \& Ajzen, I. (1975). Belief, attitude, intention and behavior: An introduction to theory and research. Reading, MA: Addison-Wesley Publishing Company.

Garcia, N. A., \& Longo, N. V. (2013). Going global: Re-framing service-learning in an interconnected world. Journal of Higher Education Outreach and Engagement, 17(2), 111-135. 
Golay, P. A. (2006). The effects of study abroad on the development of global-mindedness among students enrolled in international programs at Florida State University (Unpublished doctoral dissertation). Florida State University, Tallahassee, FL.

Gruenwald, D. A. (2008). Place-based education: Grounding culturally responsive teaching in geographical diversity. In D. Gruenwald \& G. Smith (Eds.), Place-based education in the global age (pp. 137-153). New York: Lawrence Erlbaum Associates.

Gruenwald, D., \& Smith, G. (2008). Making room for the local. In D. Gruenwald \& G. Smith (Eds.), Place-based education in the global age (pp. xiii-xxiii). New York: Lawrence Erlbaum Associates.

Gurin, P., Dey, E. L., Hurtado, S., \& Gurin, G. (2002). Diversity in higher education: Theory and impact on educational outcomes. Harvard Educational Review, 72(3), 330-366.

Hartman, E., \& Kiely, R. (2014a). A critical global citizenship. In P. Green \& M. Johnson (Eds.), Crossing boundaries: Tensions and transformation in international service-learning (pp. 215242). Sterling, VA: Stylus.

Hartman, E., \& Kiely, R. (2014b). Pushing boundaries: Introduction to the global service-learning special section. Michigan Journal of Community Service Learning, 21(1), 55-63.

Institute of International Education. (2014). Generation study abroad. Retrieved from http://www.iie.org/en/Programs/Generation-Study-Abroad

Jacoby, B. (2009). Facing the unsettling questions about service-learning. In. J. Strait \& M. Lima (Eds.), The future of service-learning: New solutions for sustaining and improving practice (pp. 90-105). Sterling, VA: Stylus Publishing.

Jones, S. R., \& Hill, K. (2001). Crossing high street: Understanding diversity through community service-learning. Journal of College Student Development, 42(3), 204-216.

Jones, S. R., Rowan-Kenyon, H. T., Ireland, S. M-Y., Niehaus, E., \& Skendall, K. C. (2012). The meaning students make as participants in short-term immersion programs. Journal of College Student Development, 53, 201-220.

Keen, C., \& Hall, K. (2009). Engaging with difference matters: Longitudinal student outcomes of co-curricular service-learning programs. Journal of Higher Education, 80(1), 59-79.

Kiely, R. (2004). A chameleon with a complex: Searching for transformation in international servicelearning. Michigan Journal of Community Service Learning, 10(2), 5-20.

Kiely, R. (2005). A transformative learning model for service-learning: A longitudinal case study. Michigan Journal of Community Service Learning, 12(1), 5-22.

Lent, R. W., Brown, S. D., \& Hackett, G. (1994). Toward a unifying social cognitive theory of career and academic interest, choice, and performance. Journal of Vocational Behavior, 45, 79-122.

Longo, N. V., \& Saltmarsh, J. (2011). New lines of inquiry in reframing international service learning into global service learning. In R. Bringle, J. Hatcher, \& S. Jones (Eds.), International service learning: Conceptual frameworks and research (pp. 169-85). Sterling, VA: Stylus.

McElhaney, K. A. (1998). Student outcomes of community service learning: A comparative analysis of curriculum-based and non-curriculum-based alternative spring break programs (Unpublished doctoral dissertation). University of Michigan, Ann Arbor, MI.

Miles, M. B., Huberman, A. M., \& Saldaña, J. (2014). Qualitative data analysis: A methods sourcebook (3rd ed.). Thousand Oaks, CA: Sage.

Niehaus, E. (2012). Alternative break programs and the factors that contribute to changes in students' lives (Unpublished doctoral dissertation). University of Maryland, College Park, MD.

Niehaus, E. (2016). Alternative breaks as a context for informal interactions with diversity. Journal of Student Affairs Research and Practice, 53(2), 160-174.

Niehaus, E., \& Crane, L. K. (2013). Act local or global? Comparing student experiences in domestic and international service-learning programs. Michigan Journal of Community Service Learning, 20(1), 31-40. 
Niehaus, E., Holder, C., Rivera, M., Garcia, C., Woodman, T., \& Dierberger, J. (2017). Exploring integrative learning in service-based alternative breaks. Journal of Higher Education, 88(6), $922-$ 946.

Niehaus, E., \& Rivera, M. (2015). Serving a stranger or serving myself: Alternative breaks and the influence of race and ethnicity on student understanding of themselves and others. Journal of College and Character, 16(4), 209-224.

Niehaus, E., \& Rivera, M. (2016). Serving a higher power: The influence of alternative break programs on students' religiousness. Journal of College Student Development, 57(4), 343-361.

Orahood, T., Kruze, L., \& Pearson, D. E. (2004). The impact of study abroad on business students' career goals. Frontiers: The Interdisciplinary Journal of Study Abroad, 10, 117-130.

Paige, R. M., \& Vande Berg, M. (2012). Why students are and are not learning abroad: A review of recent research. In M. Vande Berg, R. Paige, \& K. Hemming Lou (Eds.), Student learning abroad: What our students are learning, what they're not, and what we can do about it (pp. 29-60). Sterling, VA: Stylus.

Piacitelli, J., Barwick, M., Doerr, E., Porter, M., \& Sumka, S. (2013). Alternative break programs: From isolated enthusiasm to best practices. Journal of Higher Education Outreach and Engagement, 17(2), 87-110.

Place-Based Education Evaluation Collaborative. (2010). The benefits of place-based education: A report from the place-based education evaluation collaborative ( 2 nd ed.). Retrieved from http://promiseofplace.org/research attachments/PEEC2010 web.pdf

Plater, W. M. (2011). The context for international service learning: An invisible revolution is underway. In R. Bringle, J. Hatcher, \& S. Jones (Eds.), International service learning: Conceptual frameworks and research (pp. 29-56). Sterling, VA: Stylus.

Raudenbush, S. W., \& Bryk, A. S. (2002). Hierarchical linear models: Applications and data analysis methods (2nd ed.). Thousand Oaks, CA: Sage Publications.

Rubin, D. L., \& Matthews, P. H. (2013). Learning outcomes assessment: Extrapolating from study abroad to international service-learning. Journal of Higher Education Outreach and Engagement, 17(2), 67-86.

Schroeder, K., Wood, C., Galiardi, S., \& Koehn, J. (2009). First, do no harm: Ideas for mitigating negative community impacts of short-term study abroad. Journal of Geography, 108(3), 141-147. doi:10.1080/00221340903120866

Shahjahan, R. A., \& Kezar, A. J. (2013). Beyond the "national container": Addressing methodological nationalism in higher education research. Educational Researcher, 42, 20-29.

Simons, L., \& Cleary, B. (2006). The influence of service learning on students' personal and social development. College Teaching, 54(4), 307-319.

Skendall, K. C. (2012). Socially responsible leadership: The role of participation in short-term service immersion programs (Unpublished doctoral dissertation). University of Maryland, College Park, MD.

Smith, G. A. (2002). Going local. Educational Leadership, 60(1), 30-33.

Sobania, N.W. (2015). Introduction: The local-global nexus. In N. Sobania (Ed.), Putting the local in global education (pp. 16-35). Sterling, VA: Stylus.

Stromquist, N. P. (2002). Education in a globalized world: The connectivity of economic power, technology, and knowledge. Lanham, MD: Rowman \& Littlefield.

Sutton, S. B. (2011). Service learning as local learning: The importance of context. In R. Bringle, J. Hatcher, \& S. Jones (Eds.), International service learning: Conceptual frameworks and research (pp. 125-144). Sterling, VA: Stylus.

Uehara, A. (1986). The nature of American student reentry adjustment and perceptions of the sojourn experience. International Journal of Intercultural Relations, 10, 415-438.

Wood, C. A., Banks, S., Galiardi, S., Koehn, J., \& Schroeder, K. (2011). Community impacts of international service-learning and study abroad: An analysis of focus groups with program leaders. Partnerships: A Journal of Service-Learning \& Civic Engagement, 2(1), 
$1-23$.

Woolf, M. (2007). Impossible things before breakfast: Myths in education abroad. Journal of Studies in International Education, 11, 496-509.

Yin, R. K. (2011). Qualitative research from start to finish. New York: Guilford Press.

Zhang, Z., Zyphur, M. J., \& Preacher, K. J. (2009). Testing multilevel mediation using hierarchical linear models: Problems and solutions. Organizational Research Methods, 12(4), 659-719. 